UDC: $635.64-187$

COBISS.SR-ID: 212202764

Original research paper

Acta Agriculturae Serbica, Vol. XIX, 38 (2014); 97-103

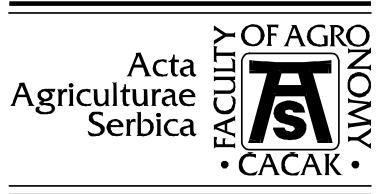

\title{
Application of Bio-stimulator Biocomplex 900 in Producing Tomato (Lycopersicon essculentum Mill.) Seedling
}

\author{
Milena Đurić, Jelena Mladenović, Radoš Pavlović \\ Faculty of Agronomy, University of Kragujevac, Serbia, \\ Jasmina Zdravković \\ Institute for Vegetable Crops, Smederevska Palanka, Serbia
}

\begin{abstract}
Applications of bio-stimulant Biocomplex 900 was studied in this paper in the production of tomato (Lycopersicon Essculentum Mill) seedling and the hybrid Belle was used. Indicators of growth and development were studied: mass of fresh root matter, stem and leaves, leaf area and the content of photosynthetic parameters in the leaf. A natural bio-stimulator was used in these studies as the ecological preparation, since it contains the seaweed Ascophyllum nodosum with high content of alginic acids, micro elements and amino acids. The application of this bio-stimulant showed very positive impact, compared to the control (untreated) variant and increased the values of almost all investigated parameters.
\end{abstract}

Key words: growth stimulants, eco preparation, tomat 


\section{Introduction}

Biostimulators are physiologically active substances that, when applied in low concentrations in agricultural production, promote the development of plants. Its impact is not the consequence of nutritional value or essential elements of physiologically active matter, but the coordination among cells, tissues and organs of plants. These matters have a wide spectra and are not very specific. One hormone can impact many various processes (Dobromilska et al. 2008; Abdel-Mowgoud et al. 2010).

Bio-stimulators contain amino acids, polysaccharides and vitamins and have a positive effect on plant development, especially on root growth, and this, on the other hand, provides the ability to adapt in unfavourable conditions (Parađiković et al. 2008).

Bearing in mind the chemical composition of Biocomplex 900 is expected that its application in hybrid tomato Belle will have a positive impact on the growth and development of plants. The basis of this preparation makes Ascophyllum nodosum seaweed which has a high content of essential amino acids (Pertuit., 1995).

The application of this preparation does not change the chemical and physical properties of the substrate for plant growing, but it even enriches it with certain microelements.

Application of bio-stimulant has particular importance in vegetable crops (when transplanted) since plants go through a very stressful period. Just at this time the root system must be provided with a sufficient amount of nutrients so the plant life proceeds normally (Vinković et al. 2009).

Biocomplex 900 contains glycosides, amino acids and tryptophan, and prolyne. Glycides represent the energetic factors of growth, since their degradation makes large amounts of energy necessary for physiological professes in plant. Synthesis of auxine is conditioned by trypophyne, without which there would be no proper development of root. The synthesis of auxin is conditioned by tryptophan, without which the root system would not develop properly. Proline has an antioxidant effect, it destroys harmful radicals that can damage cells, or even the whole plant (Nešović et al. 2003). The development of above-ground parts of the plant depends on the glycosides, amino acids tryptophan and prolyne, which affects the photosynthetic activity (Maini, 2006; Arthur et al. 2004). Bearing all this in mind the goal of this study was to research the impact of Biocomplex 900 in tomato seedling. Its appliance should enable normal development of the plant on worn out or even infected land, where it could clean the land by collecting free radicals. 


\section{Materials and methods}

The influence of Biocomplex-900 on tomato seedlings hybrids Belle was researched. This is a strong hybrid, plant is high, habitus semi-opened with large fruits (Zdravković et al. 2012). We have chosen this hybrid due to its adaptability and reliability in different growing conditions in greenhouses and in the open field.

This study has been performed in the greenhouse owned by individual produces form village Trbusani, during the spring of 2013. Tomato hybrid Belle plants have been transplanted in flowerpots volume $3 l$. Flower pots are filled with garden soil. Transplanting was performed at the phase of first 4 leaves. Trial has been set in random block system with 2 variances in 3 replications. Each variance had 20 plants.

Trial variances were:

1. Application of Biocomplex 900 in concentration $0,2 \%$, through watering

2. Control (without treatment)

Concentration of $0,2 \%$ was recommended by producer. The first treatment was during the transplantation. The second was after 15 days. One month after second treatment plants were removed from land and the following parameters were measured:

- Fresh root mass;

- Fresh plant mater mass;

- Fresh leaf mater mass;

- Leaf surface;

- The level of pigments in the leaves;

The leaf surface was determined by applying method - leaf contour on paper (Međedović et al. 2006), and the level of pigments in the leaves was determined spectrometrically by Wettsteinu (Wettstein, 1957).

Obtained results were proceeded statistically by applying the method of analysis of variance (ANOVA).

\section{Results and Discussion}

Results of the research are shown in table 1 and on Picture 1. 
Table 1 - Average value of researched parameters of development of tomato seedling by applying Biocomplex-a 900

\begin{tabular}{|c|c|c|c|c|c|c|c|}
\hline \multirow{2}{*}{$\begin{array}{l}\text { Trial } \\
\text { variances }\end{array}$} & \multirow{2}{*}{$\begin{array}{l}\text { Fresh } \\
\text { root } \\
\text { mass }(g)\end{array}$} & \multirow{2}{*}{$\begin{array}{l}\text { Fresh } \\
\text { plant } \\
\text { matter } \\
\text { mass } \\
(g)\end{array}$} & \multirow{2}{*}{$\begin{array}{l}\text { Fresh } \\
\text { leaf } \\
\text { mass } \\
(g)\end{array}$} & \multirow{2}{*}{$\begin{array}{l}\text { Leaf } \\
\text { surfac } \\
\mathrm{e} \\
\left(\mathrm{cm}^{2}\right)\end{array}$} & \multicolumn{3}{|c|}{$\begin{array}{l}\text { Pigmentation of } \mathrm{mg} / \mathrm{g} \text { fresh } \\
\text { mass }\end{array}$} \\
\hline & & & & & $\begin{array}{l}\text { Chlorophyll } \\
a\end{array}$ & $\begin{array}{l}\text { Chlorophyll } \\
b\end{array}$ & $\begin{array}{l}\text { Carot } \\
\text { enoid } \\
\mathrm{s}\end{array}$ \\
\hline $\begin{array}{l}\text { Biocompl } \\
\text { ex } 900\end{array}$ & 7,90 & 39,71 & 25,10 & 13,21 & 1,37 & 0,43 & 0,67 \\
\hline $\begin{array}{l}\text { Control } \\
\text { (without } \\
\text { treatment) }\end{array}$ & 6,60 & 27,71 & 13,41 & 9,21 & 1,01 & 0,25 & 0,25 \\
\hline $\mathrm{F}$ test & * & * & * & * & $*$ & n.s. & n.s. \\
\hline
\end{tabular}

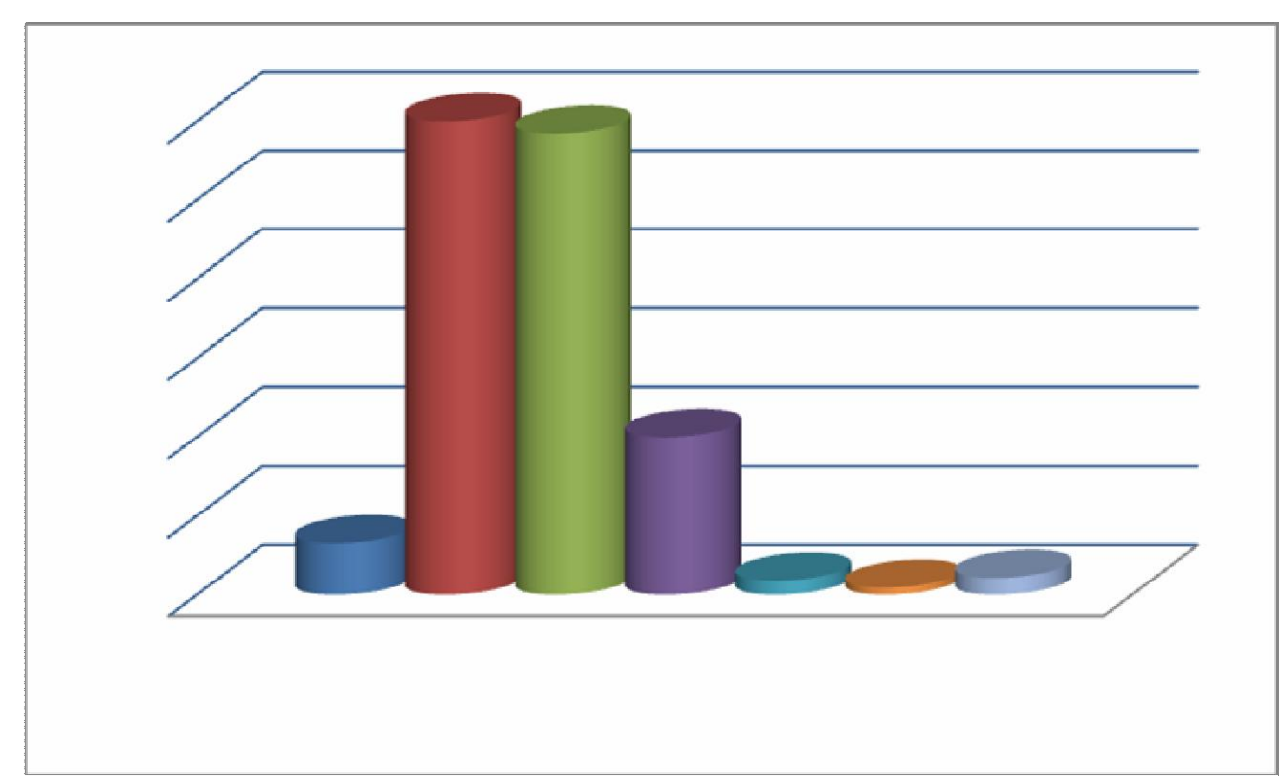

Picture 1 - Positive differences in mass (g) of: root, plant, leaf, leaf surface $\left(\mathrm{cm}^{2}\right)$, chlorophyll (mg/g) and carotenoid (mg/g) by applying Biocomplexa 900 .

Table and a Picture shows that the appliance of bio stimulator Biocomplex 900 in tomato hybrid seedling Belle comparing to control untreated variance, had a statistically significant impact on increase of fresh root mass, plant and leaves, as well as on enlargement of leaf mass, chlorophyll and carotene. 
The content of chlorophyll and carotenoid were statistically significant in treated variant. Chlorophyll and carotenoid content were statistically significant in treated variant. Having in mind that carotenoids go together with chlorophyll, whioch was expected, since the enlarged leaf surface as well as the fresh mass of root, plant and leaf enlarged the need of plant for photosynthesis. This had as a result, the increase of photosynthetic pigments, meaning plant did not suffer.

Our study gave the same results as many other studies of researchers who have worked with bio-stimulators of tomato, that were not natural, i.e. ecological origin (Blunden et al. 1996; Dobromilska et al. 2008; Abdel-Mowgoud et al. 2010; Arhur et al. 2004).

\section{Conclusion}

Based on the above findings, it is clear that the Biocomplex 900, and its application resulted in better plant growth and therefore a greater ability to adapt to adverse environmental conditions, safer production and grater ecological significance. We expect the greater application of the tested bio-stimulant in cultivation of vegetable crops, and its advantage is promotion of organic production, which can have great practical importance in the production of high quality seedling.

\section{References}

Abdel-Mawgoud,A.S., Hafez.M.M., Habib,A.M. (2010): Seaweed extract improves growth, yield and quality of different watermelon hybrids. Research Journal of Agriculture and Biological Sciences, 6 (2): 161-168.

Arthur,G.D., Stric.W.A., Van Staden, J . (2004): Effect of seaweed extract on the growth and yield of three varieties of Capsicum annum. South African Journal of Botany, 69 (2): 207-211.

Blunden,G., Jenkins, T., Yan-Wen,L. (1996): Enhanced leaf chlorop0hyll levels in plants treated with seaweed extract.J.Appl.Phycol., 8 (6): 535-543.

Dobromilska,R., Mikicink,M., Gubarewiez,K. (2008): Evalution of cherry tomato yielding and fruit mineral composition after using of Bio-algen S-90 preparation. J.Elementol., 13 (4): 491-499.

Maini,P. (2006): The experience of the first biostimulant, based on aminoacids and peptides: a short retrospective review on the Laboratory research and the practical results. Ed.Centro Scientifica Italiano deo Fertilizzanti, Fertilitas Agrorum, 1 (1): 2943.

Međedović,S., Parić,A., Pustahija,J. (2006): Uvod u biljnu fiziologiju (labor.priručnik). Šumarski fakultet Univrziteta u Sarajevu. 
Nešković,M., konjević,R., Ćula fić,Lj . (2003): Fiziologija biljaka. NNKInternational, Beograd.

Parađiković,N., $\quad$ Vinković,T., Teklić, T., Guberac,V., Milaković,Z. (2008): Primjena biostimulatora u proizvodnji presadnica rajčice. Zbornik radova 43. hrvatskog i 3. internacionalnog simpozija agronoma - Opatija, 435-438.

Pertuit,A.J. (1995): Effects of leonardite and seaweed on tomato, zinnia, and marigold seedlings. Hort.Sci., 30: 621-657.

Vinković,T., Parađiković,N., Teklić,T., Štolfa,I., Guberac,V., Vujić,D. (2009): Utjecaj biostimulatora na rast i razvoj rajčice (Lycopersicon esculentum Mill.) nakon presađivanja. Zbornik radova 44. hrvatskog i 4. internacionalnog simpozija agronoma - Opatija, 459-463.

W e t t s te in, D . (1957): Chlorophyll - lethale und der submik roskopische Formwechsel der Plastiden. Exptl. Cell. Res., 12: 427-506.

Zdravković, J., Marković, Ž., Pavlović, R., Zdravković, M. (2012): Paradajz, Monografija. Institut za povrtarstvo. Smederevska Palanka. 
EFEKAT PRIMENE BIOSTIMULATORA BIOCOMPLEX 900 U PROIZVODNJI RASADA PARADAJZA (Lycopersicon Essculentum Mill.)

\author{
Milena Đurić, Jelena Mladenović, Radoš Pavlović \\ Agronomski fakultet, Univerzitet u Kragujevcu, Srbija \\ Jasmina Zdravković \\ Institut za povrtarstvo, Smedervska Palanka, Srbija
}

\begin{abstract}
Rezime
Primene biostimulatora Biocomplex 900 isitana je u ovom radu u proizvodnji rasada paradajza (Lycopersicon Essculentum Mill.) a korišćen je hibrid Belle. Ispitivani pokazatelji rasta i razvića su: masa sveže materije korena, stabla i listova, površina lista i sadržaj fotosintetskih parametara u listu. U ovim istraživanjima korišćen je prirodni biostimulator u funkciji ekološkog preparata, obzirom da je u osnovi preparata sadržan hemijski sastav morske alge Ascophyllum nodosum i odlikuje se visokim sadržajem alginskih kiselina, mikroelemenata i aminokiselina.

Primena ovog biostimulatora u poređenju sa kontrolnom (netretiranom) varijantom pokazala je veoma pozitivan uticaj i povećanje vrednosti gotovo svih ispitivanih parametara.
\end{abstract}

Ključne reči: stimulatori rasta, eko preparat, paradajz. 